\title{
Analisis Senyawa Metabolit Sekunder dan Uji Toksisitas Ekstrak Etanol Biji Buah Alpukat (Persea americana Mill.)
}

\author{
Mira Marlindaa*, Meiske S. Sangia, Audy D. Wuntua \\ aJurusan Kimia, FMIPA, Unsrat, Manado
}

\section{KATA K UNC I}

Alpukat

Fitokimia

Toksisitas

Artemia salina

\section{KEYW OR D S}

Avocado

Phytochemical

Toxicity

Artemia salina

\begin{abstract}
A B S T R A K
Biji buah alpukat telah banyak digunakan sebagai obat tradisional, oleh karena itu diperlukan informasi ilmiah tentang kandungan kimia dan efek samping yang ditimbulkan. Tujuan penelitian ini adalah untuk menganalisis senyawa-senyawa metabolit sekunder yang terkandung dalam biji alpukat, serta menentukan toksisitas ekstrak biji alpukat berdasarkan metode Brine Shrimp Lethality Test (BST). Skrining fitokimia merupakan suatu tahap seleksi awal untuk mendeteksi golongan senyawa kimia yang terdapat dalam ekstrak tumbuhan. Skrining fitokimia meliputi uji alkaloid, uji triterpenoid dan steroid, uji tanin, uji flavonoid dan uji saponin. Uji toksisitas menggunakan metode BST dengan bioindikator larva Artemia salina Leach. Hasil yang diperoleh dianalisis dengan analisis probit menggunakan SPSS 20.0 for Windows untuk mengetahui nilaiLethal Concentration 50 ( LC $_{50}$ ). Berdasarkan skrining fitokimia, biji buah alpukat diketahui mengandung beberapa senyawa metabolit sekunder, yaitu alkaloid, triterpenoid, tanin, flavonoid dan saponin. Nilai LC $_{50}$ yang diperoleh berdasarkan uji toksisitas biji buah alpukat mentega segar dan kering, serta biji buah alpukat biasa segar dan kering, yaitu masingmasing sebesar 42,270 mg/L, 36,078 mg/L, 36,924 mg/L, dan 34,302 $\mathrm{mg} / \mathrm{L}$.

A B S T R A C T

Avocado seed has been used as traditional medicine and therefore it is necessary to have scientific information about its chemical contents and its side effects. The purpose of this study was to analyze the secondary metabolite compounds contained in avocado seeds and to determine the toxicity of avocado seed extract using the Brine Shrimp Lethality Test (BST) method. Phytochemical screening is the initial step to detect the chemical compounds contained in plant extracts. Phytochemical screening test included alkaloids, triterpenoids and steroids,tannins, flavonoids, and saponins tests. Artemia salina Leach was used as a bioindicator in toxicity testing BST method. The results were then analyzed by probit analysis using SPSS 20.0 for Windows to determine Lethal Concentration 50 (LC50) values. Based on phytochemical screening, avocado seeds contained several compounds of secondary metabolites, namely alkaloids, triterpenoids, tannins, flavonoids and saponins. LC 50 values obtained by testing the toxicity of the butter local fresh and dried avocado seeds and of the ordinary local fresh and dried avocado seeds, were $42.270 \mathrm{mg} / \mathrm{L}$, $36.078 \mathrm{mg} / \mathrm{L}, 36.924 \mathrm{mg} / \mathrm{L}$ and $34.302 \mathrm{mg} / \mathrm{L}$, respectively.
\end{abstract}

\section{Pendahuluan}

Alpukat merupakan buah yang banyak digemari oleh masyarakat Indonesia. Umumnya alpukat memiliki daging buah tebal berwarna hijau kekuningan dengan biji di tengahnya berwarna kecoklatan. Dalam dunia pengobatan, alpukat telah banyak digunakan sebagai obat tradisional untuk mengobati berbagai macam penyakit. Daging buahnya bisa mengurangi rasa sakit dan mengobati sariawan. Daun buah alpukat biasanya digunakan

*Corresponding author: Jurusan Kimia FMIPA UNSRAT, Jl. Kampus Unsrat, Manado, Indonesia 95115; Email address: m3_rh@yahoo.com Published by FMIPA UNSRAT (2012) 
untuk mengobati nyeri saraf, nyeri lambung, menurunkan darah tinggi dan mengobati batu ginjal. Selain buah dan daunnya, biji buah alpukat juga bisa digunakan untuk mengurangi kadar gula dalam darah (Hariana, 2004). Oleh sebab itu, biji buah alpukat diduga memiliki senyawa-senyawa metabolit sekunder. Untuk menganalisis senyawa-senyawa metabolit sekunder tersebut perlu dilakukan skrining fitokimia. Zuhrotun (2007) telah melakukan analisis senyawa metabolit sekunder biji buah alpukat bulat dengan membandingkan sampel biji buah alpukat bulat dengan ekstrak etanol biji buah alpukat bulat.

Senyawa aktif yang terdapat dalam tumbuhan hampir selalu toksik pada dosis tinggi, oleh karena itu daya bunuh senyawa aktif terhadap organisme hewan dapat digunakan untuk menapis ekstrak tumbuhan yang mempunyai bioaktivitas dan juga memonitor fraksi bioaktif selama fraksinasi dan pemurnian.Salah satu organisme yang sesuai untuk hewan uji adalah Artemia (udang laut) jenis Artemia salina. Keistimewaan Artemia yaitu memiliki toleransi (kemampuan beradaptasi dan mempertahankan diri) pada kisaran kadar garam yang sangat luas. A. salina Leach dapat dimanfaatkan sebagai hewan uji dalam penentuan ketoksikan suatu sari atau senyawa yang diwujudkan sebagai racun. Metode ini dikenal dengan BST (Brine Shrimp Lethality Test) (Meyer et al., dalam Makalalag, 2011).

Dalam penelitian ini dilakukan analisis senyawa metabolit sekunder biji buah alpukat mentega (hijau panjang) dan biji buah alpukat biasa (merah bundar) dalam keadaan segar dan kering serta uji toksisitas ekstrak etanol biji buah alpukat mentega dan biasa dalam keadaan segar dan kering.

\section{Metode}

\subsection{Bahan dan Alat}

Bahan utama dalam penelitian ini adalah biji buah alpukat varietas hijau panjang atau disebut alpukat mentega yang diperoleh dari perkebunan desa Maumbi Minahasa Utara, Sulawesi Utara, dengan ciri-ciri fisik: buah berukuran besar, berwarna hijau kekuningan saat matang, kulit buah licin, daging tebal berwarna kuning mentega, biji buah besar yang selanjutnya disebut sebagai alpukat A, biji buah alpukat varietas merah bundar atau disebut alpukat biasa dengan ciri-ciri fisik: buah berukuran sedang, kulit buah kasar dan mudah rusak, berwarna merah saat matang, buah berserat dan biji buah besar, yang selanjutnya disebut sebagai alpukat $\mathrm{B}$.

Bahan-bahan lainnya adalah larva A. salina, akuades, merkuri(II)klorida, kalium iodida, bismut subnitrat, asam asetat glasial, iodium, kloroform, amoniak, asam sulfat, etanol, asam klorida, bubuk magnesium, besi(III)klorida, garam dapur dan aluminium foil.

Alat yang digunakan dalam penelitian ini adalah satu set alat evaporator, desikator, pemanas listrik, timbangan digital, mortar, sudip, alat-alat gelas, kertas saring, termometer, aerator, lampu, dan kaca pembesar (lup).

\subsection{Metode Penelitian}

\subsubsection{Preparasi Sampel}

Sampel yang digunakan yaitu biji buah alpukat $A$ dan B yang segar dan kering. Untuk sampel segar, sampel dicuci dan dipotong-potong kecil kemudian dihancurkan. Untuk sampel kering, sampel dicuci kemudian dikeringanginkan selama 1 minggu, setelah itu sampel diblender hingga halus, lalu disaring dengan ayakan 65 mesh.

\subsubsection{Skrining Fitokimia}

\subsubsection{Uji Alkaloid}

Uji alkaloid dilakukan menurut Douglas et al. (Sangi et al., 2008) Sampel biji buah alpukat halus sebanyak 4 g ditambahkan kloroform secukupnya, selanjutnya ditambahkan $10 \mathrm{~mL}$ amoniak dan $10 \mathrm{~mL}$ kloroform. Kemudian larutan disaring ke dalam tabung reaksi dan filtrat ditambahkan 10 tetes $\mathrm{H}_{2} \mathrm{SO}_{4}$ $2 \mathrm{~N}$. Campuran dikocok dengan teratur, dibiarkan beberapa menit sampai terbentuk 2 lapisan. Lapisan atas dipindahkan ke dalam tiga tabung reaksi masingmasing sebanyak $1 \mathrm{~mL}$. Kemudian masing-masing tabung tersebut ditambahkan beberapa tetes pereaksi Mayer, Wagner dan Dragendorff. Apabila terbentuk endapan menunjukan bahwa sampel tersebut mengandung alkaloid, dengan pereaksi Mayer memberikan endapan putih, dengan pereaksi Wagner memberikan endapan berwarna coklat dan pereaksi Dragendorff memberikan endapan berwarna jingga.

\subsubsection{Uji Triterpenoid dan Steroid}

Uji triterpenoid dan steroid dilakukan menurut Briggs (Sangi et al., 2008). Sampel biji buah alpukat halus sebanyak 50-100 mg ditambahkan asam asetat glasial sampai semua sampel terendam, dibiarkan selama 15 menit kemudian 6 tetes larutan dipindahkan ke dalam tabung reaksi dan ditambahkan 2-3 tetes asam sulfat pekat. Adanya triterpenoid ditunjukkan dengan terjadinya warna merah, jingga atau ungu, sedangkan steroida ditunjukkan dengan terbentuknya warna biru.

\subsubsection{Uji Tanin}

Uji tanin dilakukan menurut Miranda (Sangi et al., 2008). Sampel biji buah alpukat halus sebanyak 20 mg ditambah etanol sampai sampel terendam semuanya. Kemudian ditambahkan 2-3 tetes larutan $\mathrm{FeCl}_{3}$ 1\%. Hasil positif ditunjukkan dengan terbentuknya warna hitam kebiruan atau hijau.

\subsubsection{Uji Flavonoid}

Uji flavonoid dilakukan menurut Cai (Sangi et al., 2008). Sampel biji buah alpukat halus sebanyak 200 $\mathrm{mg}$ diekstrak dengan $5 \mathrm{~mL}$ etanol dan dipanaskan selama lima menit di dalam tabung reaksi. Selanjutnya ditambah beberapa tetes HCL pekat. Kemudian ditambahkan 0,2 g bubuk Mg. Hasil positif ditunjukkan dengan timbulnya warna merah tua selama 3 menit. 


\subsubsection{Uji Saponin}

Uji saponin dilakukan menurut Simes et al. (Sangi et al., 2008). Sampel biji buah alpukat halus sebanyak 2 g dimasukkan ke dalam tabung reaksi, kemudian ditambahkan akuades hingga seluruh sampel terendam, dididihkan selama 2-3 menit, dan selanjutnya didinginkan, kemudian dikocok kuat-kuat. Hasil positif ditunjukkan dengan terbentuknya buih yang stabil.

Perlakuan uji alkaloid, uji triterpenoid dan steroid, uji tanin, uji flavonoid dan uji saponin di atas dilakukan untuk sampel biji buah alpukat A segar dan kering, serta biji buah alpukat B segar dan kering.

\subsubsection{Ekstraksi biji buah alpukat}

Ekstraksi dilakukan dengan cara maserasi. Sebanyak $20 \mathrm{~g}$ biji buah alpukat A dan B segar yang telah dihancurkan (digerus) dan biji buah alpukat $A$ dan B kering yang telah dihaluskan direndam dalam $100 \mathrm{~mL}$ pelarut etanol 70\% selama 24 jam, kemudian disaring sehingga diperoleh filtrat. Perlakuan tersebut dilakukan selama 2 hari. Tahap selanjutnya dievaporasi untuk penguapan pelarut, ekstrak dikeluarkan dari labu evaporasi dan dimasukan dalam cawan petri, kemudian disimpan di dalam desikator. Selanjutnya masing-masing ekstrak biji buah alpukat A dan B ditimbang.

\subsubsection{Penentuan Kadar Air}

Kadar air ditentukan dengan menggunakan metode Sudarmadji (1989). Sampel halus biji buah alpukat sebanyak $2 \mathrm{~g}$ dimasukkan ke dalam oven pada suhu $105^{\circ} \mathrm{C}$ selama 3 jam, kemudian dikeluarkan dari oven dan didinginkan dalam desikator selama 30 menit, setelah itu berat sampel ditimbang. Perlakuan ini dilakukan beberapa kali hingga berat sampel konstan. Kadar air dihitung berdasarkan rumus:

$$
\% \text { Kadar air }=\frac{\text { berat awal }- \text { berat akhir }}{\text { berat awal }} \times 100 \%
$$

Perlakuan di atas dilakukan untuk biji buah alpukat A dan B yang segar dan kering.

\subsubsection{Uji Toksisitas Menggunakan Metode BST}

\subsubsection{Penyiapan larva A. salina Leach}

Penyiapan larva udang dilakukan dengan mengambil telur $A$. salina ditimbang sebanyak $1 \mathrm{~g}$.
Penetasan dilakukan dengan cara merendam telur tersebut dalam air laut buatan sebanyak $1 \mathrm{~L}$ dan diberi penerangan serta diaerasi selama 48 jam. Air laut buatan dibuat dengan cara melarutkan $35 \mathrm{~g}$ garam dapur dalam $1 \mathrm{~L}$ air kemudian disaring.

\subsubsection{Penyiapan Larutan Stok}

Untuk pembuatan larutan stok, ekstrak ditimbang sebanyak $200 \mathrm{mg}$ kemudian dilarutkan sampai $100 \mathrm{~mL}$ dengan air garam buatan, kemudian dari larutan stok $2000 \mathrm{mg} / \mathrm{L}$ dibuat pengenceran 500 $\mathrm{mg} / \mathrm{L}, 100 \mathrm{mg} / \mathrm{L}, 50 \mathrm{mg} / \mathrm{L}, 25 \mathrm{mg} / \mathrm{L}$ dan 12,5 mg/L. Untuk kontrol ( $0 \mathrm{mg} / \mathrm{L}$ ) dilakukan tanpa penambahan ekstrak.

\subsubsection{Uji Toksisitas}

Uji toksisitas dilakukan pada masing-masing ekstrak sampel segar dan kering. Disiapkan wadah untuk pengujian, untuk masing-masing konsentrasi ekstrak sampel membutuhkan 6 wadah dan 1 wadah sebagai kontrol. Selanjutnya pada tiap konsentrasi larutan dimasukan 10 ekor larva udang. Pengamatan dilakukan selama 24 jam terhadap kematian larva udang, di mana setiap konsentrasi dilakukan dua kali pengulangan dan dibandingkan dengan kontrol. Pengamatan jumlah larva udang yang mati dihitung tiap selang waktu 6 jam, yaitu pada jam ke-6, 12, 18 dan 24.

\subsubsection{Analisis Statistik}

Data hasil penelitian uji toksisitas diolah dan disajikan dalam bentuk tabel dan grafik. Data dari uji toksisitas tersebut akan dianalisis dengan Analisis Probit menggunakan SPSS 20.0 for Windows untuk mengetahui harga $\mathrm{LC}_{50}$.

\section{Hasil dan Pembahasan \\ 3.1 Ekstraksi dan Kadar Air Biji Buah Alpukat}

Rendemen ekstrak yang diperoleh dari $20 \mathrm{~g}$ biji buah alpukat dalam $100 \mathrm{~mL}$ pelarut etanol 70\% dan kadar air biji buah alpukat dapat dilihat pada Tabel 1.

Berdasarkan Tabel 1 terlihat bahwa rendemen sampel kering biji buah alpukat $A$ dan biji buah alpukat $B$ lebih tinggi dibandingkan rendemen sampel segar. Hal ini disebabkan oleh kadar air sampel kering jauh lebih sedikit dibandingkan dengan kadar air sampel segar.

Tabel 1 - Rendemen ekstrak dan kadar air biji buah alpukat.

\begin{tabular}{|l|c|c|}
\hline \multicolumn{1}{|c|}{ Sampel } & Rendemen Ekstrak (\%) & Kadar Air Sampel (\%) \\
\hline Biji buah alpukat A segar (AS) & 8,157 & 59.807 \\
\hline Biji buah alpukat A kering (AK) & 12,058 & 13.494 \\
\hline Biji buah alpukat B segar (BS) & 5,305 & 56.466 \\
\hline Biji buah alpukat B kering (BK) & 7,562 & 12.868 \\
\hline
\end{tabular}

Kadar air biji buah alpukat ditentukan untuk mengetahui banyaknya kandungan air dalam biji alpukat segar dan kering. 


\subsection{Skrining Fitokimia}

Berdasarkan hasil skrining fitokimia, senyawasenyawa metabolit sekunder yang terkandung dalam biji buah alpukat dapat dilihat pada Tabel 2 .

Berdasarkan Tabel 2 biji buah alpukat mengandung senyawa metabolit sekunder yaitu

Tabel 2 - Hasil skrining fitokimia biji buah alpukat

\begin{tabular}{|c|c|c|c|c|c|}
\hline & \multirow{2}{*}{ Metode Pengujian } & \multicolumn{4}{|c|}{ Hasil } \\
\hline & & AS & AK & BS & BK \\
\hline Alkaloid & $\begin{array}{l}\text { Pereaksi Mayer } \\
\text { Pereaksi Wagner } \\
\text { Pereaksi Dragendorff }\end{array}$ & $\begin{array}{c}++ \\
+ \\
++\end{array}$ & $\begin{array}{c}+ \\
++ \\
+\end{array}$ & $\begin{array}{c}++ \\
+ \\
++\end{array}$ & $\begin{array}{c}+ \\
++ \\
+\end{array}$ \\
\hline $\begin{array}{l}\text { Triterpenoid } \\
\text { Steroid }\end{array}$ & $\begin{array}{l}\text { Uji Liebermann-Bucchard } \\
\text { Uji Liebermann-Bucchard }\end{array}$ & $\begin{array}{c}++ \\
-\end{array}$ & $\begin{array}{c}++ \\
-\end{array}$ & $\begin{array}{c}++ \\
-\end{array}$ & $\begin{array}{c}++ \\
-\end{array}$ \\
\hline Tanin & $\mathrm{FeCl}_{3}$ & ++ & +++ & ++ & +++ \\
\hline Flavonoid & Etanol & + & +++ & ++ & +++ \\
\hline Saponin & Aquades & +++ & +++ & +++ & +++ \\
\hline
\end{tabular}

$\mathrm{AS}=$ biji buah alpukat $\mathrm{A}$ segar, $\mathrm{AK}=$ biji buah alpukat $\mathrm{A}$ kering, $\mathrm{BS}=$ biji buah alpukat $\mathrm{B}$ segar, $\mathrm{BK}=\mathrm{biji}$ buah alpukat B kering.

$(-)=$ tidak terdeteksi, $(+)=$ intensitas lemah, $(++)=$ intensitas kuat, $(+++)=$ Intensitas sangat kuat
Menurut Zuhrotun (2007) senyawa-senyawa metabolit sekunder yang terdapat dalam biji buah alpukat bentuk bulat yaitu tanin, flavonoid, triterpenoid,monoterpenoid dan sedangkan saponin hanya terdeteksi dalam ekstrak.

Dari Tabel 2 terlihat adanya perbedaan antara sampel segar dan kering untuk uji tanin dan flavonoid. Meskipun diuji dengan berat yang sama, pada sampel kering kandungan tanin dan flavonoid lebih positif dibandingkan sampel segar. Hal ini diduga disebabkan oleh kadar air sampel kering jauh lebih sedikit daripada kadar air sampel segar.

Menurut Harborne (1987), untuk mengekstraksi suatu tumbuhan tergantung pada tekstur dan kandungan air bahan tumbuhan yang diekstraksi serta jenis senyawa yang akan diisolasi.

\subsubsection{Alkaloid}

Berdasarkan hasil skrining fitokimia, diketahui bahwa biji buah alpukat A segar dan kering serta biji buah alpukat $B$ segar dan kering mengandung senyawa alkaloid. Hal ini terlihat dari endapan yang terbentuk. Pereaksi Mayer akan bereaksi dengan alkaloid dan membentuk endapan berwarna putih. Dengan pereaksi wagner akan beraksi dengan alkaloid dan membentuk endapan berwarna coklat sedangkan dengan pereaksi Dragendorff membentuk endapan berwarna jingga (Robinson, 1995).

\subsubsection{Triterpenoid dan Steroid}

Menurut Harborne (1987) bahwa kandungan terpenoid/steroid dalam tumbuhan diuji dengan nantinya akan memberikan warna jingga atau ungu untuk terpenoid dan warna biru untuk steroid.Uji ini menggunakan metode Liebermann-Bucchard yang alkaloid, tanin, flavonoid, triterpenoid dan saponin. Hasil ini berbeda dengan skrining fitokimia yang dilakukan terhadap sampel dan ekstrak etanol biji buah alpukat bentuk bulat yang telah dilakukan oleh Zuhrotun (2007). didasarkan pada kemampuan senyawa triterpenoid dan steroid membentuk warna oleh $\mathrm{H}_{2} \mathrm{SO}_{4}$ pekat pada pelarut asetat glasial yang membentuk warna jingga. Bedasarkan hasil skrining fitokimia, diketahui bahwa biji buah alpukat A segar dan kering serta biji buah alpukat B segar dan kering mengandung senyawa Triterpenoid. Hal ini terlihat dari perubahan warna yang terjadi setelah penambahan asam sulfat pekat, yaitu warna jingga dan ungu. Pada uji steroid menunjukkan hasil negatif, karena tidak terjadi perubahan warna biru.

\subsubsection{Tanin}

Berdasarkan hasil skrining fitokimia, diketahui bahwa biji buah alpukat A segar dan kering serta biji buah alpukat $B$ segar dan kering mengandung senyawa Tanin. Hal ini dapat dilihat dari perubahan warna yang terjadi pada saat penambahan larutan $\mathrm{FeCl}_{3}$ 1\% yaitu warna hijau kehitaman.

Pada penambahan larutan $\mathrm{FeCl}_{3} 1 \%$ diperkirakan larutan ini bereaksi dengan salah satu gugus hidroksil yang ada pada senyawa tanin. Pereaksi $\mathrm{FeCl}_{3}$ dipergunakan secara luas untuk mengidentifikasi senyawa fenol termasuk tanin (Robinson, 1995). Hasil pengujian yang dilakukan pada tabung reaksi yang menggunakan larutan $\mathrm{FeCl}_{3}$ menunjukkan timbulnya warna hijau.

\subsubsection{Flavonoid}

Hasil skrining fitokimia menunjukkan bahwa biji buah alpukat A segar dan kering serta biji buah alpukat B segar dan kering memiliki kandungan senyawa flavonoid. 
Warna merah pada uji flavonoid disebabkan karena terbentuknya garam flavilium (Achmad, 1986) menurut reaksi berikut:

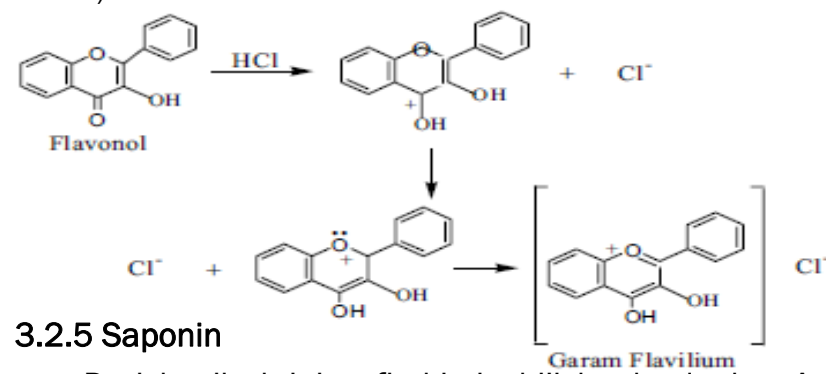

Dari hasil skrining fitokimia biji butah talpukat $A$ segar dan kering serta biji buah alpukat B segar dan kering mengandung senyawa saponin. Hal ini terlihat dari busa stabil yang dihasilkan.

Menurut Robinson (1995) senyawa yang memiliki gugus polar dan nonpolar bersifat aktif permukaan sehingga saat dikocok dengan air, saponin dapat membentuk misel.Pada struktur misel, gugus polar menghadap ke luar sedangkan gugus nonpolarnya menghadap ke dalam. Keadaan inilah yang tampak seperti busa.

\subsection{Uji Toksisitas Menggunakan Metode BST}

Hasil analisis probit menggunakan SPSS 20.0 dapat dilihat pada Tabel 3.

Berdasarkan Tabel 3 nilai LC50 untuk ekstrak biji buah alpukat A segar dan kering serta biji buah alpukat B segar dan kering kurang dari 1000 mg/L.
Nilai ini menunjukkan bahwa biji buah alpukat bersifat toksik.

Nilai LC50 dari biji buah alpukat pada Tabel 3 lebih kecil dibandingkan dengan nilai $\mathrm{LC}_{50}$ daging buah pare yang sama-sama memiliki khasiat sebagai antidiabetes Nilai LC $_{50}$ untuk daging buah pare adalah 130,437 mg/L (Bawa, 2009). Hal ini diduga disebabkan oleh senyawa-senyawa metabolit sekunder yang terkandung dalam sampel. Dalam biji buah alpukat terkandung senyawa alkaloid, triterpenoid, tanin, flavonoid dan saponin, sedangkan hasil uji fitokimia isolat aktif toksik pada daging buah pare hanya mengandung senyawa triterpenoid (Bawa, 2009).

Pengamatan dilakukan selama 24 jam, pada tiap selang waktu 6 jam. Pengamatan secara berulang-ulang ini bertujuan untuk mengetahui pengaruh waktu terhadap kematian pertama dari larva, dengan adanya perbedaan konsentrasi ekstrak etanol.

\section{Kesimpulan}

Berdasarkan hasil skrining fitokimia, senyawasenyawa metabolit sekunder yang terdapat pada biji buah alpukat A segar dan kering, serta biji buah alpukat B segar dan kering adalah alkaloid, triterpenoid, tanin, flavonoid, dan saponin.

Tabel 3 - Hasil Analisis Probit Menggunakan SPSS 20.0.

\begin{tabular}{|l|c|}
\hline \multicolumn{1}{|c|}{ Jenis Alpukat } & Nilai $\mathrm{LC}_{50}(\mathrm{mg} / \mathrm{L})$ \\
\hline Alpukat A Segar (AS) & 42,279 \\
\hline Alpukat A Kering (AK) & 36,078 \\
\hline Alpukat B Segar (BS) & 36,924 \\
\hline Alpukat B Kering (BK) & 34,302 \\
\hline
\end{tabular}

Hasil pengujian toksisitas ekstrak biji buah alpukat A segar dan kering serta alpukat B segar dan kering menghasilkan nilai $\mathrm{LC}_{50}$ masing-masing sebesar $42,270 \mathrm{mg} / \mathrm{L}, 36,078 \mathrm{mg} / \mathrm{L}, 36,924 \mathrm{mg} / \mathrm{L}$, dan $34,302 \mathrm{mg} / \mathrm{L}$. Nilai ini menunjukkan bahwa biji buah alpukat bersifat toksik.Berdasarkan nilai tersebut, terlihat bahwa biji buah alpukat B kering memiliki nilai $\mathrm{LC}_{50}$ paling rendah.

\section{Daftar Pustaka}

Achmad, S.A. Kimia Organik Bahan Alam. Karnunika, Jakarta.1986

Bawa, I. G. A. G. Isolasi dan Identifikasi Golongan Senyawa Toksik DariDaging Buah Pare (Momordica charantia L.). Jurnal Kimia. 2009, 2, 117-124.
Harborne, J.B. Metode Fitokimia, Penuntun Cara Modern Menganalisis Tumbuhan. Terjemahan K. Padmawinata dan I. Soediro. ITB, Bandung.1987

Hariana, A. Tumbuhan Obat dan Khasiatnya. Penebar Swadaya, Depok.2004

Makalalag, A. Skrining Fitokimia dan Uji Toksisitas Akut Ekstrak Etanol Daun Turi (Sesbania Grandiflora Pers). [Sripsi]. UNSRAT, Manado.2011

Robinson, T. Kandungan Senyawa Organik Tumbuhan Tinggi. Diterjemahkan oleh Prof. Dr. Kosasih Padmawinata. ITB, Bandung.1995

Sangi, M.; Runtuwene, M.R.J.; Simbala, H.E.I. dan Makang, V.M.A. Analisis Fitokimia Tumbuhan Obat di Kabupaten Minahasa Utara.Chemistry Progress. 2008, 1,47-53.

Sudarmaji, S.; Haryono, B. dan Suhardi. Prosedur Analisis untuk Bahan Makanan dan Pertanian. Libery, Yogyakarta.1989 
